\title{
Meningkatkan Pelayanan Administrasi Publik di Indonesia
}

\author{
Rita Komalasari ${ }^{1}$, Nurhayati ${ }^{2}$, Cecep Mustafa ${ }^{3}$ \\ ${ }^{1}$ Ilmu Kesehatan Masyarakat, Fakultas Kedokteran, Universitas Yarsi, Jakarta, Indonesia \\ ${ }^{2}$ Program Studi, Fakultas, Universitas Prasetiya Mulya, BSD, Indonesia \\ ${ }^{3}$ Peneliti Independen \\ Email: ${ }^{1}$ rita.komalasari2012@gmail.com, ${ }^{2}$ nurhayati.phd1@gmail.com, ${ }^{3}$ cecepmustafa97@gmail.com
}

\begin{abstract}
This paper presents the findings to improve public administration services. For the first time, the findings presented in this paper contribute to knowledge and to addressing problems, as well as to provide direct and tangible benefits to the service of the wider community. The research method presented in this paper is a qualitative study involving interviews with participants who are District Court Judges and observations in two selected courts. The findings presented in this paper will have an impact on improving services administration in public sector in Indonesia.
\end{abstract}

Keywords: improving, service administration, public, Indonesia.

\begin{abstract}
Abstrak
Makalah ini menyajikan temuan-temuan dalam rangka mengingkatkan pelayanan administrasi publik. Untuk pertama kali nya, temukan yang disajikan dalam makalah ini memberikan kontribusi untuk pengetahuan dan untuk menangani masalah serta untuk memberikan manfaat langsung dan nyata bagi pelayanan masyarakat yang lebih luas. Metode penelitian yang disajikan dalam makalah ini berupa studi kualitatif yang melibatkan wawancara dengan partisipan yang merupakan Hakim Pengadilan Negeri dan observasi di dua pengadilan terpilih. Hasil temuan yang disajikan dalam makalah ini akan memberikan dampak dalam upaya meningkatan pelayanan administrasi di sektor publik di Indonesia.
\end{abstract}

Kata Kunci: peningkatan, layanan administrasi, publik, Indonesia.

\section{A. PENDAHULUAN}

Dalam dua dekade terakhir, telah terdapat peningkatan jumlah studi, khususnya di negaranegara barat, mengeksplorasi hubungan antara faktor-faktor budaya peradilan pada saat menjatuhkan putusan. Hal ini terkait dengan budaya peradilan yang dalam hal ini terkait dengan pengetahuan yang mendasari praktik sehari-hari dan membentuk nilai-nilai hakim seperti budaya birokrasi. Patut dicatat bahwa sejak awal tahun 2003 telah terjadi peningkatan jumlah penelitian, khususnya di negara-negara barat, yang mengeksplorasi hubungan antara budaya peradilan dan kinerja mereka dalam mengelola beban kasus pengadilan. Durose (2011), misalnya, menemukan bahwa pada konteks birokrat, hakim pengadilan tingkat pertama tunduk pada pelaksanaan pengadilan yang lebih tinggi. Dengan demikian, hakim di pengadilan tingkat pertama diharapkan dapat memuaskan hakim di pengadilan yang lebih tinggi. Inilah yang digambarkan Lipsky sebagai strategi penanganan yudisial. Studi Durose menunjukkan bagaimana budaya birokrasi mereka, yang menuntut kepatuhan terhadap arahan hakim senior, mempengaruhi para hakim. Ini mencerminkan beberapa perdebatan tentang strategi koping peradilan dalam literatur. Perdebatan ini terjadi antara konteks internasional seputar budaya peradilan. Seorang pendukung strategi koping peradilan mengklaim bahwa hakim yunior mengikuti pendapat hakim senior. Di satu sisi, hakim bersifat "independen" (Biland \& Steinmetz, 2014) dan diizinkan melaksanakan kebijaksanaan yudisial. Sebaliknya, hakim "bergantung" pada budaya birokrasinya, yang perlu memberikan pertanggungjawaban kepada ketua pengadilan atas kinerja mereka dalam mengelola beban perkara di pengadilan. Budaya birokrasi dan orientasi manajerial ini dapat menumbangkan interpretasi yudisial tentang keadilan menjadi hanya mempercepat beban kasus pengadilan, yang dianggap sebagai kriteria penting dari pengadilan yang lebih tinggi (Durose, 2011). Karena budaya birokrasi mereka dan dibawah tujuan pengadilan yang salah untuk mewujudkan 
efisiensi pemrosesan kasus, mereka dapat menghukum para pelanggar yang ingin menggunakan hak mereka untuk diadili lebih berat daripada mereka yang mengaku bersalah. Meskipun studi tentang hubungan antara faktor budaya peradilan ketika penjatuhan putusan meningkat sejak 2013, sebagian besar didorong oleh budaya birokrasi mereka di negara-negara barat, fokusnya terutama untuk memuaskan mereka yang berada di pengadilan yang lebih tinggi, sekali lagi mengabaikan struktur penonton yang lebih luas (yaitu politik, publik dan komunitas agama) --menanggapi pengabaian umum dari struktur yang lebih luas dari penonton, banyak studi tentang penjatuhan putusan mengeksplorasi struktur yang lebih luas dari penonton tentang penjatuhan putusan, termasuk determinan publik. Studi mereka sangat penting dalam mengeksplorasi masalah legitimasi yang mendasari penjatuhan putusan. Ini mendefinisikan legitimasi dalam studi ini sebagai sejauh mana lembaga tampaknya mencerminkan harapan orang lain dalam kinerja yang sah. Dalam hal akuntabilitas publik, Langbroek, (2014) memfokuskan pada penjatuhan putusan yang mencerminkan mekanisme akuntabilitas langsung kepada masyarakat. Misalnya, di Amerika Serikat, hakim dipilih secara demokratis oleh komunitas, dan karena itu, interpretasi yudisial tentang keadilan menunjukkan akuntabilitas langsung mereka kepada komunitas (Langbroek 2014). Ini mengakui cara, dalam budaya barat, hakim melakukan pekerjaan politik dengan menafsirkan keadilan dalam penjatuhan putusannya. Patut juga dicatat bahwa sejak awal 2013 ada satu studi yang mengeksplorasi perspektif peradilan di negaranegara Asia, terutama dalam hubungannya antara komunitas Buddhis dan penjatuhan putusan di Thailand (Yarampancha, 2013). Namun, perlu dicatat bahwa sejauh mana interpretasi hakim terhadap keadilan tampaknya mencerminkan akuntabilitas mereka terhadap struktur audiens yang lebih luas (yaitu, ranah politik, publik dan komunitas agama) yang terkait dengan masalah penggunaan narkoba masih belum dieksplorasi. Hubungan antara umat Islam dan akuntabilitas hakim Indonesia saat menjatuhkan penjatuhan putusan inilah yang akan penulis bahas lebih lanjut dalam penelitian ini.

\section{B. PELAKSAAAN DAN METODE}

Dari segi pelaksanaan dan metode, studi berbasis wawancara kualitatif ini melibatkan hakim Indonesia sebagai partisipan. Penulis mendapat persetujuan etik untuk penelitian ini dari University of Stirling. Penulis ini juga mengadopsi beberapa strategi untuk mengidentifikasi studi yang relevan dalam literatur. Pertama, penulis mengidentifikasi studi kunci di lapangan dan menggunakannya sebagai sumber referensi lebih lanjut. Kedua, setiap dokumen baru yang dipelajari memungkinkan saya untuk mengidentifikasi studi relevan lainnya dan menjadi akrab dengan jurnal yang relevan dengan bidang tersebut. Daftar judul yang menurut penulis relevan dengan penelitian tersebut adalah: International Journal of Drug Policy, Justice Quarterly, International Journal of Court Administration.

Konseptualisasi penelitian ini berasal dari penulis ini, mantan yang mengidentifikasi diri sebagai hakim, tetapi juga biografi penulis karena penulis lebih akrab dengan tekanan suara dan tantangan dari hakim Pengadilan yang lebih rendah. Sebelumnya pernah bekerja sebagai Pengadilan Negeri, penulis memiliki pengalaman sebelumnya tentang sistem peradilan di Indonesia. Penulis melakukan semua kerja lapangan untuk penelitian ini dalam kapasitas penulis sebagai peneliti. Kekhawatiran penulis tentang perspektif yudisial tentang penjatuhan putusan berasal dari perjalanan belajar penulis yang timbul dari pengalaman penulis sebagai hakim praktik dan mahasiswa doktoral. Selama tujuh tahun penulis, sebagai salah satu dari 3.034 hakim pengadilan negeri di negara ini, penulis telah mengirim pelaku narkoba yang tidak terlalu serius ke penjara dengan penjatuhan putusan standar minimum mulai dari satu hingga empat tahun, termasuk wanita dan dewasa muda. Namun demikian, penulis berpendapat bahwa ketentuan pidana penjara tersebut terlalu keras bagi para pelaku narkoba, yang basis keterlibatannya dalam pelanggaran narkoba pada banyak faktor, termasuk faktor ekonomi seperti pendapatan. Selain itu, penulis menganggap kejahatan narkoba tidak separah kejahatan pembunuhan. Sebelumnya, penulis merasa berkonflik terkait peran penulis dalam menghukum pelaku narkoba ringan. Terkait perilaku menghukum para hakim, mereka cenderung menghadapi kritik dari masyarakat dan media dimana penjatuhan putusan yang lebih rendah diberikan untuk pelanggaran narkoba, karena hal ini dianggap hakim terlalu lunak terhadap kejahatan narkoba. Sementara itu, di kalangan masyarakat, pelanggaran narkoba dipandang sebagai masalah moral, menurut agama Islam, dan penjatuhan putusan hakim akan dipandang dengan kecurigaan sebagai memihak para pelaku narkoba. Namun, ketika penulis telah menanyakan pelaku setelah divonis narkoba apa yang menurut mereka penjatuhan putusan yang adil, kebanyakan dari mereka meminta penjatuhan putusan yang lebih rendah atau kesempatan untuk menerima perawatan narkoba. Namun, dalam yurisdiksi penulis, tidak ada sumber daya yang layak untuk mendukung pengobatan narkoba di komunitas. Oleh karena itu, setiap upaya untuk menghukum pelaku narkoba dengan pengobatan akan sia-sia. Merasa bahwa menghukum pelaku narkoba ke penjara akan menjadi pilihan terbaik karena akan melindungi publik, sejak mempelajari 
praktik penjatuhan putusan secara internasional, penulis menyadari bahwa mungkin ada pilihan penjatuhan putusan yang lebih efektif yang tersedia bagi para pelanggar narkoba. Pilihan penjatuhan putusan ini mungkin benar untuk hakim Indonesia lainnya, yang mungkin mengalami kurangnya pemahaman tentang alternatif selain penjatuhan putusan penjara. Menghukum seorang pelaku narkoba di bawah umur dapat menyentuh persepsi dan laporan pengadilan. Penulis menganggap bahwa latar belakang penulis ini mungkin bermanfaat dalam menangani aspek ini. Dengan mempelajarinya, penulis memaparkan pemahaman kontemporer tentang perspektif dan pengalaman hakim, yang dapat membantu pemahaman yang lebih baik tentang pidana narkoba dalam mewujudkan keadilan di Indonesia.

Mengenai penyampaian keadilan dalam konteks Indonesia, penulis mengidentifikasikan dari pelatihan yudisial bahwa pemidanaan terhadap pelaku narkoba harus mencakup minimal tiga dimensi, yuridis, filosofis, dan sosiologis. Yuridis adalah tentang penjatuhan putusan mati; filosofis dalam pengertian tujuan penjatuhan putusan dan sosiologis tentang penerimaan publik. Oleh karena itu, penulis menganggap ketiga dimensi tersebut penting dalam konteks Indonesia. Studi, yang menjadi dasar Makalah ini menawarkan wawasan tentang tiga dimensi penjatuhan putusan dalam praktik. Meskipun Ketua Mahkamah Agung diizinkan untuk belajar, mereka tidak memberikan pengaruh apa pun pada kerja lapangan, analisis atau interpretasi data.

Pada akhirnya, karena budaya peradilan sebelumnya tidak berbicara tentang kepedulian publik, para peserta berharap suara mereka benarbenar diakui melalui studi ini. Dari intonasi yang provokatif, tanggapan yang bijaksana, dan ekspresi yang bijaksana, tanggapan para peserta tidak hanya untuk menjawab pertanyaan wawancara penulis; mereka juga tampaknya mengungkapkan keprihatinan mereka bahwa sebagian besar pelaku narkoba ringan yang dibawa ke pengadilan berasal dari 'kelas bawah (1)'. Persepsi yudisial tentang ketidaksetaraan struktural mendorong tanggung jawab moral para hakim panel. Pengaruh pemeriksaan, ketegangan dengan polisi, Badan Narkotika Nasional (BNN), dan kejaksaan kerap menjadi tantangan. Tantangan ini membuat sebagian besar peserta menyesuaikan interpretasi mereka tentang keadilan ke dalam keadaan. Ini menyebabkan minoritas substansial dari peserta untuk melaksanakan kebijaksanaan mereka dengan 'minoritas substansial' dari penulis mengacu pada minoritas numerik dari peserta penelitian yang berbagi perspektif yang sama.

\section{HASIL DAN PEMBAHASAN}

Bagian hasil dan pembahasan ini menyajikan referensi khusus untuk penjatuhan putusan berdasarkan tanggung jawab moral dan melaksanakan kebijaksanaan yudisial. Selanjutnya, ia memberikan rekomendasi dan arahan penelitian di masa depan untuk meningkatkan layanan publik dan operasi pemerintah.

\section{Dasar Moral Dalam Menjatuhkan Putusan}

Sebagian besar dari peserta minoritas (yaitu Lima dari 31) menyampaikan bahwa seseorang harus menjunjung tinggi tanggung jawab moral baik pada saat pembahasan penjatuhan putusan dan di sidang pengadilan. Perhatikan, misalnya, komentar Hakim 19: "Menurut saya pengguna narkoba telah menjadi korban kriminalisasi" (Hakim 19). Dari perspektif hakim ini, mengidentifikasi mereka secara strategis tepat untuk mendapatkan dukungan publik untuk tanggapan simpatik. Mengenai pendekatan individual untuk menghukum pelanggar narkoba di bawah umur, sebagian kecil dari peserta menunjukkan bahwa latar belakang pelaku di balik perdagangan narkoba dan efek stigmatisasi dari penjatuhan putusan dipertimbangkan dengan penuh kasih. Dilihat dengan cara ini, minoritas substansial dari hakim yang berpartisipasi menganggap pendekatan penjatuhan putusan individual. Misalnya seperti yang disebutkan oleh Hakim 14 di bawah ini:

... Pengertian kepemilikan harus diperjelas karena tidak adil menerapkan hukum narkoba tanpa mempertimbangkannya dari berbagai sudut. Misalnya, kami mempertimbangkan apakah kasus tersebut menarik perhatian publik, efek dari penjatuhan putusan, latar belakang di balik perdagangan narkoba dan apakah itu untuk berbisnis atau karena kurangnya pendapatan atau pendapatan yang berlebihan. (Hakim 14)

Seperti yang diilustrasikan oleh kutipan di atas, kasus yang menarik perhatian publik atas latar belakang peredaran narkoba, sering dianggap oleh sebagian kecil peserta terkait dampak penjatuhan putusan terhadap publik. Oleh karena itu, sebagian kecil peserta sedang mempertimbangkan efek stigmatisasi dari penjatuhan putusan. Sementara minoritas substansial dari musyawarah peserta tentang pendekatan individual terhadap penjatuhan putusan tampaknya implisit mengandalkan penilaian 'berbasis risiko', ada harapan implisit dari mereka, yaitu bahwa penilaian mereka akan meminimalkan perilaku berisiko dari para pelanggar hukum. Misalnya, dialog antara Hakim 14 (Panel) dan Pelanggar yang diambil dari hasil observasi persidangan menggambarkan penilaian 'berbasis risiko' ini:

Hakim 14 Panel: Berapa lama Anda menggunakan narkoba?

Pelaku: Tiga bulan 
Hakim 14 Panel: Kapan Anda tahu tentang ganja? Pelaku: Sejak SMA

Hakim 14 Panel: Apa yang kamu lakukan saat SMA?

Pelaku: Saya menggunakan narkoba

Hakim 14 Panel: Mengapa Anda menerima narkoba?

Pelaku: Saya menerima narkoba dengan bayaran Rp50.000 (sekitar $€ 4,00$ )

Hakim 14 Panel: Apa yang terjadi jika Anda tidak menggunakan narkoba?

Pelanggar: Saya terlalu banyak berpikir. (Diambil dari Catatan Pengamatan Sidang Pengadilan, Hakim Panel 14)

Dari kutipan di atas, kita dapat melihat bahwa Hakim 14 (Panel) yang berpartisipasi memperhatikan risiko pelaku menjadi ketergantungan pada narkoba. Temuan ini menunjukkan bahwa minoritas substansial dari hakim yang berpartisipasi di dua yurisdiksi dengan penuh kasih mempertimbangkan penjatuhan putusan mereka dari berbagai sudut, termasuk berdasarkan 'penilaian risiko', dan mempertimbangkan peran mereka untuk meminimalkan efek stigmatisasi dari penjatuhan putusan pelanggar.

\section{Pengaruh Opini Publik dan Media}

Faktor lain yang mempersulit pengejaran keadilan tampaknya berasal dari opini publik dan gambaran media yang menghukum para pelaku narkoba di bawah umur. Meskipun hakim tidak dipilih oleh masyarakat, beberapa peserta (yaitu Sembilan dari 31) menjelaskan bahwa kadang-kadang mereka mempertimbangkan opini publik tentang penjatuhan putusan. Kutipan berikut menggambarkan hal ini:

Jika penjatuhan putusannya harus menghukum pelanggar, maka opini publik seharusnya tidak berpengaruh. Namun, jika penjatuhan putusannya non-vonis, maka opini publik bisa mempengaruhi. Namun, opini publik bukanlah acuan utama, ini hanya satu bahan; itu telah menjadi bumbu, dan itu menjadi bagian garam. (Hakim 9)

Kutipan di atas menyoroti pemahaman masyarakat bahwa terdakwa tidak bersalah, dan oleh karena itu mereka meminta kepada hakim untuk membebaskan pelaku. Anggota komunitas ini mengetahui alibi tersebut dan memahami bahwa orang tersebut tidak bersalah. Sebagian kecil peserta sadar bahwa masyarakat menginginkan pelaku dibebaskan dan menganggap ada alibi. Dalam situasi ini, hakim menerima opini publik tersebut, dan hal ini menyebabkan terdakwa tidak divonis. Oleh karena itu, dapat dianggap bahwa peran opini publik bertindak sebagai "tambahan" untuk non-keyakinan. Di Pengadilan Pedesaan, sebagian kecil dari peserta (yaitu Dua dari 11) menunjukkan bahwa harapan publik dianggap memastikan bahwa penjatuhan putusan memenuhi harapan masyarakat: "Jika kami yakin bahwa pelaku adalah pengguna narkoba, maka kami akan menghukum mereka sebagai seorang pemakai narkoba. Ini yang diharapkan masyarakat, semoga kalimat kita membantu "(Hakim 27). Seperti yang ditunjukkan, begitu keyakinan yudisial bertemu dengan harapan masyarakat, Hakim 27 akan berharap penjatuhan putusan mereka akan membantu pengguna narkoba. Oleh karena itu, harapan publik menjadi sumber pengetahuan yang menambah nilai justifikasi penjatuhan putusan. Namun justifikasi bentuk pengetahuan dari masyarakat ini perlu dipertimbangkan dengan hatihati. Di Pengadilan Perkotaan, beberapa peserta (yaitu Dua dari 17) menunjukkan bagaimana mereka berhati-hati dalam menyaring opini publik: Kita harus membedakan tingkat opini publik, dan apakah itu opini jurnalis. Oleh karena itu, jika jurnalis menulis tentang pendapatnya sendiri, maka itu akan dianggap sebagai opini jurnalis yang dipublikasikan dan belum tentu opini publik. Jika opini komunitas diberitakan oleh wartawan, kami anggap opini publik. (Hakim 9)

Seperti yang diilustrasikan oleh kutipan di atas, solusi untuk menjawab harapan publik adalah dengan menyaringnya dan menanamkan nilai budaya dalam mempertimbangkan opini publik. Namun, keduanya bertujuan untuk kejelasan yang menyaring ekspektasi publik yang seringkali mempengaruhi penjatuhan putusan yudisial. Positioning seperti itu kontras dengan pandangan hakim tentang otonom. Dalam membenarkan penjatuhan putusannya, beberapa peserta menilai dampak dari menyaring opini publik ke dalam penjatuhan putusannya. Seperti Hakim 14, misalnya, menyebutkan: "... Jika kita menganggap perkara ini menarik perhatian publik, berpengaruh pada penjatuhan penjatuhan putusan (Hakim 14). Kutipan ini menggambarkan bahwa kasus yang menarik perhatian publik ini kerap menjadi bahan pertimbangan beberapa peserta terkait dampak penjatuhan putusan terhadap masyarakat. Karena itu, beberapa peserta membenarkan penjatuhan putusannya berdasarkan ekspektasi publik.

\section{Menjalankan keadilan dan pelayanan publik}

Minoritas substansial dari hakim Pengadilan Pedesaan yang berpartisipasi (yaitu dua dari 11) merekomendasikan perlunya hakim untuk memiliki peran aktif dalam menafsirkan opsi penjatuhan putusan dengan BNN setempat, para pelanggar, dan keluarga pelanggar:

Saya punya peran ganda sebagai petugas hubungan masyarakat, jadi saya dapat menginformasikan kepada kepala BNN setempat (2) di yurisdiksi pedesaan tentang SKB (3) dan tentang menyediakan rehabilitasi ... Kami juga memberi tahu keluarga mereka di sidang pengadilan bahwa tujuannya dari kalimat-kalimat ini adalah 
pendekatan pengobatan yang lebih aktif. (Hakim 28)

Hakim 28 menunjukkan bahwa peran aktif dalam proses negosiasi di dalam dan di luar ruang sidang akan memungkinkan BNN setempat, para pelanggar, dan keluarga pelaku untuk mendapatkan informasi yang lebih baik tentang hak mereka atas pengobatan. Selama penelitian lapangan, tampaknya ada kurangnya kesadaran tentang Perjanjian Bersama tentang ketentuan pengobatan (SKB) saat ini antara jaksa, polisi yang menjadi saksi, dan pengacara pelaku. Dalam situasi ini, muncul kekhawatiran apakah para pelanggar menyadari hak mereka atas pengobatan. Untuk mencari hubungan kekuatan yang seimbang antara para pihak dalam negosiasi, sebagian besar minoritas Pengadilan Pedesaan yang berpartisipasi di dua yurisdiksi bertujuan untuk menyediakan pengacara untuk membela terdakwa dan berbicara dalam mitigasi. Kutipan dari persidangan berikut menggambarkan hal ini:

Panel Hakim 24: Apakah Anda memahami dakwaan? Kami akan memberikan pengacara gratis untuk Anda; Pemerintah akan membayar pengacara ini. Proses persidangan akan dilanjutkan minggu depan untuk mendengarkan pembelaan Anda dari pengacara Anda (Ringkasan Catatan Pengamatan sidang pengadilan, Panel Hakim 24).

Seperti yang disoroti oleh Hakim 24 (Panel) dalam persidangan, tujuannya adalah untuk menyeimbangkan hubungan kekuasaan antara para pelanggar dan jaksa. Pada persidangan, sebagian kecil dari Pengadilan Kota yang berpartisipasi (yaitu Dua dari 17) dengan sengaja mencoba untuk menyeimbangkan hubungan kekuasaan ini. Pertimbangkan, misalnya, komentar Hakim 9 (Perkotaan):

Kadang-kadang, hakim harus mendukung pelaku karena pelaku, yang tidak memiliki pengacara pembela, berada dalam posisi yang rentan. Dalam situasi ini, hakim harus menyeimbangkan dan memposisikan pelaku secara setara dan menjunjung tinggi hak-hak pelaku terhadap jaksa. Hanya dalam kondisi ini gagasan tentang pengadilan yang adil akan ada. (Hakim 9)

Kutipan di atas menyoroti upaya Hakim 9 untuk menyeimbangkan hubungan kekuasaan dengan 'berdiri di belakang pelanggar'. Hakim 9 berusaha untuk menyeimbangkan posisi pelaku secara setara dan mendukung hak-hak pelaku terhadap jaksa. Dalam situasi jaksa dianggap mengajukan pertanyaan tendensius, hakim dapat meminta jaksa mengajukan pertanyaan terbuka. Dalam situasi jaksa dianggap terlalu banyak menggunakan istilah hukum, hakim dapat meminta jaksa untuk menggunakan bahasa yang sederhana. Dalam situasi di mana jaksa dianggap membuat gugatan tentang penjatuhan putusan, hakim dapat meminta pelaku untuk melakukan gugatan balik. Bagi Hakim 9, penegakan prosedur penegakan merupakan strategi yang disengaja untuk mendamaikan ketidakseimbangan kekuasaan antara jaksa dan pelanggar. Mereka menunjukkan upaya lain untuk menyeimbangkan hubungan kekuasaan dalam minoritas substansial dari kapasitas Pengadilan Kota yang berpartisipasi untuk memastikan bahwa dukungan rehabilitasi tersedia. Kutipan berikut menggambarkan hal ini:

Begitu kita menjatuhkan penjatuhan putusan ke rehabilitasi, maka biaya rehabilitasi harus menjadi beban negara dan bukan bagi pelanggar. Oleh karena itu, kami tidak melihat latar belakang sosial pelaku atau apakah pelaku itu kaya atau miskin. Oleh karena itu, setelah divonis rehabilitasi, biaya akan ditanggung oleh negara atau rumah sakit umum. (Hakim 8)

Seperti yang ditunjukkan, Hakim 8 (Urban) berusaha untuk memastikan bahwa kelas sosial pelaku tidak menjadi penghalang akses pelaku ke dukungan rehabilitasi. Biaya rehabilitasi menjadi beban negara setelah majelis hakim menghukum pelaku rehabilitasi. Mereka meminta hakim untuk mempertimbangkan penerimaan pelaku atas penjatuhan putusan narkoba. Oleh karena itu, peran hakim juga disajikan dalam bentuk penjatuhan putusan yang dapat diterima di mata para pelanggar. Karena hakim dapat melakukannya, taktiknya adalah dengan mengabaikan penjatuhan putusan. Sebagian kecil dari peserta (yaitu Dua dari 31) mencatat bahwa menanggapi keluarga pelaku yang datang kepadanya dan meminta bantuan akan mengurangi lamanya penjatuhan putusan: 'Saya tidak melihat masalah dengan mengizinkan intervensi selama lamanya penjatuhan putusan. penjatuhan putusan tidak terlalu jauh dari standar minimum (Hakim 2). Pada acara Judge 2, menyimpang dari standar minimum dipandang dapat diterima bagi pelanggar dan keluarga pelaku untuk menegosiasikan bentuk penjatuhan putusan yang dapat diterima. Minoritas substansial dari Pengadilan Pedesaan yang berpartisipasi mencari kesepakatan di antara anggota panel hakim. Pertimbangkan, misalnya, komentar (Pedesaan) Hakim 23: 'Pada pengangkatan pertama saya sebagai hakim, Hakim 24, salah satu anggota kami, saya berkata kepada Hakim 24: bagaimana jika kita mengkategorikan pelanggar. Mereka memutuskan kesepakatan yudisial untuk menghukum pelaku rehabilitasi oleh hakim tiga panel. Dengan demikian, penjatuhan putusan untuk rehabilitasi hasil dari kesepakatan yang telah dirundingkan.

Minoritas substansial menyampaikan pesan tentang perlunya hakim untuk peka dalam 
menanggapi pelanggar yang hadir di pengadilan karena menggunakan narkoba untuk rekreasi tanpa disertai informasi dan penilaian yang memadai untuk mendukung tuntutan mereka. Ini adalah pandangan dari minoritas substansial dari Pengadilan Kota yang berpartisipasi bahwa mereka seharusnya tidak menghukum para pelanggar yang menggunakan narkoba. Ini tidak berarti bahwa dia hanya mengambil pendekatan yang lunak, tetapi sebagai strategi yang dapat diterima, pengadilan harus mulai dengan pendekatan yang lunak terhadap pelanggaran dan perluasan narkoba setelah mendapatkan dukungan publik yang lebih luas. Bagaimana ini disajikan mungkin tergantung pada pembawa pesan. Dalam peran mereka sebagai petugas hubungan masyarakat, minoritas substansial dari Pengadilan Kota yang berpartisipasi menjelaskan bahwa, kadang-kadang, mereka memanfaatkan liputan media untuk mengirim pesan kepada publik bahwa mereka berusaha untuk mengikuti aturan:

Itu (penjatuhan putusan) dihargai , juga oleh Badan Narkotika Nasional Republik Indonesia (BNN) dan oleh sektor sukarela anti anarki bagi pengguna narkoba (GRANAT). Kasus ini juga dilaporkan di Detik (4) (surat kabar online). Mereka semua menghargainya. (Hakim 4)

Komentar dari Hakim 4 (Urban) di atas menggambarkan bentuk keadilan sosial ini. Hakim 4 menilai bahwa liputan media adalah kesempatan yang sangat baik untuk menyampaikan pesan yang sampai ke publik, bahwa aturan-aturan dipatuhi di salah satu Pengadilan Pedesaan, Hakim 28 menawarkan pendekatan unik tentang cara menangani media. Hakim 28 menyebutkan bahwa peran media sangat membantu dalam menyebarkan secara strategis pendekatan yudisial terhadap pemberian pengobatan, terutama ketika hakim sudah memiliki hubungan yang bersahabat dengan media. Hakim 28 menilai sosialisasi tentang Kesepakatan Bersama enam kementerian (SKB) tentang ketentuan pengobatan itu strategis. Komentar hakim 28 sangat tepat:

Setelah keluar dari penjatuhan putusan minimum, jaksa mempertanyakan. Kemudian kami menawarkan mereka penjelasan; kami menggunakan SKB sebagai dasar penjatuhan putusan kami ... Saya menawarkan mereka salinan SKB dan, juga, terus memberi tahu mereka ... Saya membagikan SKB ini melalui media, dan juga; Saya terus menginformasikan kepada media bahwa, jika ada anggota masyarakat yang menggunakan narkoba, akan lebih baik dirujuk ke rehabilitasi. (Hakim 28)

Kutipan di atas menyoroti hubungan strategis Hakim 28 dalam menyebarkan rujukan pengguna narkoba ke rehabilitasi. Mereka harus membina hubungan dengan media. Bagi Hakim 28, ini merupakan strategi yang disengaja untuk menghadirkan keadilan sosial kepada publik. Hubungan strategis hakim diproses melalui koordinasi antar lembaga dan berbagi informasi. Hakim 28 percaya bahwa komunikasi antar lembaga harus dipupuk secara proaktif, dan Hakim 28 akan bekerja sama dengan media untuk membangun kerja sama dan berbagi informasi. Kerja sama antarlembaga inilah yang menyalurkan lebih banyak "opini publik yang terinformasi" dan harapan publik yang lebih masuk akal dan realistis untuk merehabilitasi pengguna narkoba:

Saya dapat menginformasikan kepada Kepala BNN di wilayah perdesaan tentang SKB dan tentang penyediaan rehabilitasi. Setelah beberapa kali upaya oleh media untuk membantu menginformasikan kepada masyarakat tentang SKB. Proses rehabilitasi dimulai sebelum mereka membawa kasus tersebut ke pengadilan. Kami juga menasehati keluarga mereka, di persidangan, bahwa tujuan penjatuhan putusan ini lebih merupakan pendekatan untuk pengobatan. (Hakim 28) Disini, Hakim 28 (Pedesaan) menyoroti minoritas substansial dari hubungan hakim Pengadilan Pedesaan yang berpartisipasi dengan BNN setempat, media dan publik dalam mencari dukungan yang lebih luas untuk rehabilitasi pelanggar. Minoritas substansial dari upaya Pengadilan Pedesaan yang berpartisipasi dan dukungan media, dalam menginformasikan BNN setempat dan publik tentang kesepakatan untuk memberikan rehabilitasi, membentuk proses rehabilitasi sebelumnya sebelum kasus tersebut dibawa ke pengadilan. Dalam upaya mereka untuk mewujudkan keadilan sosial, sebagian kecil peserta menyoroti pentingnya membentuk kebijakan Mahkamah Agung dan Pemerintah. Ada variasi yang sangat besar yang ada di antara pengadilan yang berbeda. Di Pengadilan Kota, sebagian kecil peserta menjelaskan bahwa upaya mereka mendapat dukungan dari Mahkamah Agung. Dari tahun 2009 hingga 2014, tampaknya ada beberapa perubahan dalam bagaimana kebijakan Mahkamah Agung menangani pelaku narkoba di bawah umur. Dengan demikian, upaya penegakan keadilan tercermin dalam bentuk dukungan dari Mahkamah Agung. Mereka menunjukkan upaya mewujudkan keadilan dalam pernyataan berikut: "... Alhamdulillah Mahkamah Agung mendengarkan pendapat saya (lima tahun lalu). Hal ini saya tunjukkan dalam peraturan internal MA (SEMA) dan peraturan eksternal Mahkamah Agung (PERMA) "(Hakim 6).

\section{Pembahasan}

Bagian ini bertujuan untuk membahas konteks studi secara keseluruhan, terutama temuan-temuan tentang tantangan keseimbangan dalam mewujudkan keadilan dan melakukan pelayanan 
publik. Dalam kondisi seperti itu di mana minoritas substansial dari hakim yang berpartisipasi menerima kepercayaan dan kepercayaan publik, harapan publik dan penggambaran media seringkali menentukan apakah pelaku narkoba di bawah umur harus dipenjara atau difasilitasi untuk mendapatkan dukungan rehabilitasi. Istilah "masyarakat" yang digunakan di sini merujuk pada pelaku, keluarga pelaku, pengunjung di dalam ruang sidang, protes masyarakat, informan anonim saat hakim bertemu dengan masyarakat, dan komunitas Islam Sunni. Harapan publik mengenai dukungan rehabilitasi bagi para pelaku narkoba di bawah umur tampaknya memfasilitasi munculnya model rehabilitasi. Harapan publik dianggap oleh sebagian kecil hakim yang berpartisipasi sebagai sumber pengetahuan yang menambah nilai pada justifikasi dukungan rehabilitasi. Dalam kondisi di mana beberapa hakim yang ikut serta mendapat kecurigaan publik atas isu korupsi, kondisi tersebut dapat membuat hakim berada dalam situasi yang memalukan. Kondisi ini dapat membuat citra reputasi peradilan secara keseluruhan terdiskreditkan. Kondisi ini memiliki konsekuensi bagi masing-masing hakim: mereka melihat penjatuhan putusan penjara atas pelanggaran narkoba sebagai cara untuk melindungi sebagian besar hakim yang berpartisipasi dari prasangka sosial. Hal ini menunjukkan bahwa pembenaran untuk penjatuhan putusan penjara merupakan subjek bersyarat dari kepercayaan publik karena Masyarakat sering melihat dukungan rehabilitasi sebagai tanda korupsi yang menguntungkan para pelanggar yang merusak kinerja peradilan. Sebagian besar peserta menghindari tuduhan publik. Kita dapat melihat bukti ini sebagai tanda bahwa sering membenarkan pemenjaraan sebagai upaya yudisial untuk meminimalkan penyimpangan kinerja. Dari sini akan terlihat bahwa dalam situasi pengenaan sanksi yang bersyarat dan tunduk pada penerimaan publik, peserta studi ini ditantang untuk menyajikan presentasi yang seimbang antara mewujudkan keadilan dan memberikan pelayanan publik.

Dalam konteks supremasi hukum dan pelayanan administrasi publik dalam konteks ini, sebagian besar hakim yang berpartisipasi masih dapat mengajukan aplikasi hukum untuk mencapai keadilan dalam pemidanaan. Mereka menyadari adanya kode hukum yang keras, yang menimbulkan persoalan seputar keadilan. Mereka juga menyadari pentingnya penerimaan publik dalam penjatuhan putusan. Kesadaran mereka tentang isu-isu seputar keadilan dan penerimaan publik mengarah pada situasi di mana mereka berusaha menghadirkan keseimbangan antara mewujudkan keadilan dan pelayanan publik. Sebagai pegawai negeri, mereka tahu bahwa mereka diharapkan dapat memberikan pelayanan yang prima untuk memenuhi harapan masyarakat. Untuk melakukannya, mereka menampilkan interaksi dengan komunitas. Misalnya, mereka menunjukkan kasih sayang dan pada saat itu diharapkan secara moral mencerminkan harapan masyarakat akan keadilan moral yang berdasarkan ajaran Islam Sunni. Dalam situasi ini, pengaruh tersebut membentuk individu untuk beradaptasi dengan ekspektasi situasional. 'Hakim yang berbelas kasih' di pengadilan studi menunjukkan kepekaan terhadap pelaku narkoba di bawah umur, dan ini mendorong minoritas substansial dari hakim yang berpartisipasi untuk mendefinisikan kembali opsi penjatuhan putusan di luar penjara. Pilihan ini termasuk pengurangan penjatuhan putusan untuk membebaskan pelaku narkoba di bawah umur dari penjara lebih cepat dan memungkinkan mereka untuk menerima perawatan di luar penjara. Kami menafsirkan demonstrasi belas kasih yudisial dan pendekatan suportif di pengadilan studi sebagai respons yang dapat diterima di mata publik.

\section{PENUTUP}

\section{Simpulan}

Sebagai simpulan, untuk mendapatkan tanggapan yang dapat diterima dari publik, sebagian besar hakim yang berpartisipasi juga mengadopsi pendekatan humanistik yang mempertimbangkan aspek hak asasi manusia dari pelaku narkoba di bawah umur. Minoritas substansial dari hakim yang berpartisipasi juga berusaha untuk menginformasikan kepada publik bahwa pendekatan yang ada untuk perang melawan narkoba telah kehilangan arah. Minoritas substansial dari hakim yang berpartisipasi memiliki peran ganda sebagai petugas hubungan masyarakat. Peran ini memungkinkan mereka untuk berbagi ketentuan pengobatan (SKB) dengan media. Untuk melakukannya, sebagian besar hakim yang berpartisipasi memanfaatkan liputan media untuk mengirimkan pesan kepada publik tentang pendekatan yudisial dalam penyediaan pengobatan. Mereka akan berbagi informasi dengan wartawan di kantor peserta setiap hari. Mereka membagikan ketentuan pengobatan (SKB) dengan media untuk memastikan pemahaman rujukan pelaku di bawah umur ke rehabilitasi. Kemudian, komentar dari media dan publik digunakan untuk menyesuaikan interpretasi mereka tentang keadilan. Dengan cara ini, mereka menyebarkan pendekatan mereka dan mempertimbangkan opini publik sehingga mereka bisa mendapatkan wawasan tentang tingkat penerimaan publik.

\section{Saran}

Makalah ini memberikan pertimbangan bahwa kesadaran yudisial tentang isu-isu seputar keadilan dan penerimaan publik mengarah pada situasi di 
mana mereka berusaha untuk menghadirkan keseimbangan antara mewujudkan keadilan dan pelayanan administrasi publik.

\section{Ucapan Terima Kasih}

Penulis berterima kasih kepada para peserta penelitian atas perkenanyanya berpartisipasi dalam penelitian ini.

\section{E. DAFTAR PUSTAKA}

Biland, É and Steinmetz, H. (2014) The judiciary and the boundaries of street level bureaucracy: family judges in France and Canada. Glasgow. ECPR General Conference.

Dewi. (2012). Perlindungan hukum bagi korban penyalahgunaan narkotika. Undang-Undang Nomor 35 Tahun 2009 tentang Narkotika. Jurnal Fakultas Hukum Universitas Udayana, 1 (1), 1-22.

Durose, Catherine (2011). "Revisiting Lipsky: Front-line work in UK local governance." Political studies 59, no. 4: 978-995. https://doi.org/10.1111/j.14679248.2011.00886.x

Pelayanan Penjara Indonesia (2013). Data narapidana. (Layanan Penjara Indonesia). http://smslap.ditjenpas.go.id/public/krl/current/ monthly/year/2013/month/7.

Jangkar (2013). Pelanggaran hak asasi manusia yang terkait dengan undang-undang antinarkoba di Indonesia. Tinjauan Berkala Universal PBB Sesi ketiga belas dari Kelompok Kerja UPR dari Dewan Hak Asasi Manusia (Harm Reduction International dan Asian Harm Reduction Network). http://lib.ohchr.org/HRBodies/UPR/Documents /session13/ID/JS1_UPR_IDN_S13_2012_Joint Submission1_E.pdf.

Lai, G. Fransiska, A. \& Birgin, R. (2013). Kebijakan obat di Indonesia. Konsorsium Kebijakan Obat Internasional (IDPC). Makalah Singkat).

http://idhdp.com/mediaimport/28817/idpcbriefing-paper_drug-policy-in-indonesia.pdf .

Langbroek, P. M. (2014). International Journal for Court Administration. International Journal, 1.

Mulyadi. (2012). Penjatuhan putusan terhadap penyelundup dan pengguna narkoba: penelitian tentang penerapan prinsip, teori, dan norma praktik di pengadilan. Pusat Penelitian Mahkamah Agung Indonesia, hal. 147.
Romindo, R., \& Ameylia, N. (2019). Sistem Informasi Pengarsipan Pada Kantor Notaris Efrina Nofiyanti Kayadu,SH., M.Kn Berbasis Web Dengan Metode Waterfall. Riset dan EJurnal Manajemen Informatika Komputer, 8185.

Yampracha, S. (2013). Memahami budaya penjatuhan putusan Thailand. [Disertasi Doktor Tidak Diterbitkan]. Universitas Strathclyde, Glasgow, Britania Raya. 